\title{
FAMILY PERCEPTION ABOUT THEIR PRESENCE OR NOT IN A PEDIATRIC EMERGENCY SITUATION
}

\author{
Fernanda Luisa Buboltz ${ }^{1}$, Andressa da Silveira², Eliane Tatsch Neves ${ }^{3}$, Julia Heinz da Silva ${ }^{4}$, Janete Severo de \\ Carvalho $^{5}$, Kellen Cervo Zamberlan ${ }^{6}$
}

${ }^{1}$ Doctoral student, Programa de Pós-Graduação em Enfermagem (PPGEnf), Universidade Federal de Santa Maria (UFSM). Nurse UFSM. Santa Maria, Rio Grande do Sul, Brazil. E-mail: fernandabuboltz@hotmail.com

${ }^{2}$ Doctoral student, PPGEnf/UFSM. Professor in Nursing, Universidade Federal do Pampa. Santa Maria, Rio Grande do Sul, Brazil. E-mail: andressadasilveira@gmail.com

${ }^{3}$ Post-doctoral degree in Public Health Nursing. Professor Curso de Graduação and PPGEnf/UFSM. Santa Maria, Rio Grande do Sul, Brazil. E-mail: eliane.neves@ufsm.br

${ }^{4}$ Master's student, PPGEnf/UFSM.CAPES scholarship student. Santa Maria, Rio Grande do Sul, Brazil E-mail: juheinz@hotmail. com.br

${ }^{5}$ Nurse. Administrative technician in education, Hospital Universitário de Santa Maria. Santa Maria, Rio Grande do Sul, Brazil. E-mail: deviga@ibest.com.br

${ }^{6}$ M.Sc. in Nursing. Nurse, Hospital Universitário, Universidade Federal de Pelotas. Pelotas, Rio Grande do Sul, Brazil. E-mail: kellencz@ hotmail.com

\begin{abstract}
The objective was to understand the perception of family members who experienced an emergency situation in relation to their presence or not during the child's treatment in the Pediatric Emergency Department. A qualitative study developed in a Pediatric Emergency Department. The study subjects consisted of ten relatives who had experienced an emergency situation. Data collection was through semi-structured interviews and data were submitted for thematic content analysis. The results showed that among the ten relatives interviewed only one said that they preferred not to remain with the child during the emergency situation. Regarding the clinical condition of the children, five of them had special health care needs. Previous negative situations had influenced the family member's choice of staying during the assistance. Considering the benefits of family presence, it is recommended that nursing teams develop strategies which can facilitate the inclusion of the family in child care in any situation, while respecting the uniqueness of each person.
\end{abstract}

DESCRIPTORS: Child. Caregivers. Family. Emergency medical services. Pediatric nursing.

\section{PERCEPÇÃO DE FAMILIARES SOBRE SUA PRESENÇA OU NÃO EM SITUAÇÃO DE EMERGÊNCIA PEDIÁTRICA}

RESUMO: Objetivou-se compreender a percepção de familiares que vivenciaram a situação de emergência, em relação à sua permanência ou não durante o atendimento à criança em Pronto-Socorro Pediátrico. Pesquisa qualitativa desenvolvida em um Pronto-Socorro Pediátrico. Os sujeitos do estudo foram de familiares que vivenciaram a situação de emergência. A coleta de dados se deu por meio de entrevistas semiestruturadas que foram transcritas e submetidas à análise de conteúdo temática. Os resultados apontaram que, dos dez familiares entrevistados, somente um referiu preferir não permanecer junto à criança durante a situação de emergência. Quanto à situação clínica das crianças, cinco das dez possuíam necessidades especiais de saúde. Situações anteriores negativas influenciaram a opção por acompanhar o atendimento. Considerando os benefícios dessa permanência, recomenda-se que a enfermagem desenvolva estratégias que facilitem a inclusão do familiar na assistência à criança em qualquer situação, respeitando a singularidade de cada pessoa.

DESCRITORES: Criança. Cuidadores. Família. Serviços médicos de emergência. Enfermagem pediátrica.

\section{PERCEPCIÓN DE LA FAMILIA SOBRE SU PRESENCIA O NO EN SITUACIONES DE EMERGENCIA PEDIÁTRICA}

RESUMEN: El objetivo fue conocer la percepción de la familia que vivió una situación de emergencia con respecto a su presencia o no en el cuidado de niños en la Sala de Emergencia Pediátrica. Estudio cualitativo desarrollado en la Sala de Emergencia Pediátrica con diez familiares que experimentaron una situación de emergencia. La recolección de datos fue través de entrevistas semiestructurados y ellos fueron sometidos a análisis de contenido temática. Mostraron que de los diez familiares entrevistados, sólo uno dijo que no prefiere permanecer con el niño durante la emergencia. Acerca de la situación clínica de los niños, cinco de ellos tenían necesidades especiales de salud. Situaciones negativas anteriores influenciaron en la elección de permanecer durante la asistencia. Teniendo en cuenta los beneficios de esta permanencia, se recomienda que la enfermería desarrolle estrategias que faciliten la inclusión de la familia, respetando la singularidad de cada persona.

DESCRIPTORES: Niño. Familia. Cuidadores. Servicios médicos de emergencia. Enfermería pediátrica. 


\section{INTRODUCTION}

The humanization of health care is a current and growing demand, especially in child health. Providing comprehensive and humanized care to the child and its family are the main challenges for health services.

The pediatric humanization strategies should consider the family as an active subject in the care of family members. Thus, it should also be included by health professionals as part of the care process. ${ }^{1}$ When viewing the family as a unit of care, it is possible to detect the interactions between its members and their implications for the child care. The family context as an active part in child care and the adoption of a humane dimension are increasingly present in daily nursing, as well as in scientific studies. ${ }^{2}$

Illness is always a traumatic event for the child and its family, especially when the treatment requires hospitalization. In this context, it is essential that the health team consider the family as an important agent in child care and provide conditions so that the family can follow and participate in this process.

In the past, parental presence in pediatric hospital inpatient units was not allowed and visits were restricted. Over the years, this reality has changed and parents have acquired the right to remain with the patient throughout the hospitalization period. However, during painful, invasive emergency procedures, many health professionals still restrict the parents' $^{\prime}$ presence. $^{3}$

Although research and international guidelines defend the family's presence in emergency situations, it still remains divergent between health teams and, as a result, is rarely adopted in practice. ${ }^{4}$

However, in some health institutions, the presence of family during invasive, painful and emergency procedures is being encouraged and being incorporated in referral hospitals throughout the world..$^{3-5}$ International research authors defend the presence of parents during emergency care because they believe that the presence of a family member can provide support and security for the child. ${ }^{6-7}$ Thus, the development of research on the subject reflects a change in the care model, giving an increasingly important role to the family's presence during the emergency procedures. ${ }^{5}$

In this sense, the presence of family during emergency procedures has been an issue often debated among health professionals worldwide.
There are no policies that regulate the presence or lack of family presence with the patient in emergency situations, causing differences in the positioning of the professionals involved. The study shows that health teams are not familiar with the concept of family members witnessing emergency procedures. $^{4}$

Faced with this, health teams of the Pediatric Emergency Department (PED) are constantly faced with the question of the family member being present or not during emergency treatment. The international literature emphasizes that this is an issue that requires development in order to enable the teams working in emergency services to use this practice on behalf of patient care at risk of life based on humanization. In this sense, the necessity to listen to the family's opinions in relation to the desire and the need to stay or not stay with the child in emergency situations is justified in this study. ${ }^{8}$

Given the above, we questioned: what is the perception of family members who have experienced an emergency situation in the Pediatric Emergency Department, in regards to being present or not during the emergency treatment? Thus, the objective was to understand the perception of family members who experienced the emergency situation regarding their presence or not in the care of children in the Pediatric Emergency Department.

\section{METHOD}

This is a qualitative, descriptive and exploratory study, developed in a PED in a teaching hospital in southern Brazil. This constitutes as a reference for pediatric care in emergency rooms in the city and region.

The study subjects consisted of ten families who experienced an emergency situation of children treated in the study setting. They were initially selected from information collected in the record book of the PED and invited to participate in the study at the time that they were found accompanying the child during hospitalization in the pediatric clinic of the hospital which is the setting of the study. Family members who showed cognitive and/or emotional limitations to participate in the interview and family members of children with clinical instability at the time of the interview were excluded from the research. The period of data collection was from November 2013 to September 2014. 
A large data collection period was necessary to make it possible to achieve an adequate number of subjects as the study setting had a great demand for outpatient care. In this PED only 3\% of cases were characterized as emergencies according to a study developed in this area of service in 2012. ${ }^{9}$

We used a semi-structured interview technique with a previously used and tested questionnaire. The guiding question of the interview was: Did you stay with the child during the emergency treatment? Tell me what was this experience was like? Subsequently, the interviews were transcribed and the material was submitted for thematic content analysis. For this step, we followed the methodological proposal of thematic content analysis, the three key stages of the method included: pre-analysis, material exploration and treatment of results. ${ }^{10}$

The pre-analysis phase consisted of organization of the material which needed to be analyzed in order to make it operational and to systematize initial ideas. ${ }^{10}$ Thus, we sought to identify issues related to the object and purposes of the study. This phase was divided into floating reading, choice of documents and preparation of material.

The second stage of content analysis consisted of the exploration of the material, where the raw data were processed and organized and aggregated into units, which led to a description of the relevant content characteristics. ${ }^{10}$ At this stage, coding (identification of issues) and categorization (approximation of related topics for the constitution of the themes) was carried out. The third and final step consisted in processing and interpretation of the obtained results.

The study was approved by the Ethics Committee of the institution under the number of Protocol: 18519513.0.0000.5346 in view of Resolution No. 466/12 of the National Health Council. ${ }^{11}$ To ensure anonymity of respondents, we used one alphanumeric code with the initial " $\mathrm{F}$ " followed by ordinal numbers according to the order in which the interviews were transcribed.

\section{RESULTS}

From the total amount of the relatives interviewed, nine were mothers of children and only one was the father. Emergency situations experienced by the family of the study were characterized by seizures, head injuries, cardiac arrest, exogenous poisoning, among others.

The age of participants ranged from 22 to 43 years of age and the level of education of each participant was obtained which ranged from incomplete elementary school to complete high school participation. The family income varied between one and four regional minimum wages (considering the value of the regional minimum wage is $\$ 259.88$ American dollars in January 2014).

The results showed that, of the ten families interviewed, only one preferred not to stay with the child during the emergency treatment, but all subjects remained during the hospitalization period. Five out of the ten family members, were family members of children with special health needs (CSHCN), which had already needed emergency care at other times; the remaining were family members of children who had witnessed an emergency situation for the first time. No family demonstrated knowledge of the legislation related to family presence or lack of with children during emergency care. Commenting on their stay during emergency care, family members presented arguments to support their preference to stay: [...] permanence is especially important for the child [...] (F2).

[...] the best thing is to be with the child at this time, we have to be with the child whatever the time (F5).

[...] help, giving the mother support. I think this counts a lot too, he has to know that he has someone there. I remember that when I was a child [...] I liked that she [the family member's own mother] stayed by my side, so I believe it's the same for my child [...] (F6).

[...] the child feels safer, being with the mother or the father, than being alone. [...] And she is already afraid of doctors, nurses, so being with a companion makes her feel safer (F10).

The interviewed family members wanted to stay with the child during the emergency, because they believed the child may feel safer in this hostile environment, where it can cause fear and despair. They believed that the family must be with the child at all times, including in situations of crisis, such as a medical emergency. Furthermore, they stated that it is preferable to stay with the child due to the benefits of fathermother-child bonding, reporting also that it can provide peace of mind, at the same time, offering emotional and affective support. 
The family also defended their stay in emergencies because they consider observing the treatment provided as important: [...] I found it very important to see what was happening to my son during that time of emergency [...] how he was reacting, what they are doing, what procedure and the care they were giving him. Really seeing everything well, seeing what was happening to him, making sure he was being well taken care of and that my son was in good hands (F5).

[...] If I wasn't in the way of things, of course I would like to stay there on the side watching, even to make me feel more relaxed, knowing it's bad, or good, because, like it or not, it takes a long time to hear someone say, 'Look, the situation is good or bad' [...] (F6).

I watched all of the procedure that they did ... [the professionals] moving as fast and as best they could because he needed it [...] you are in agony waiting on the outside, not knowing what to do and no one comes to you to say anything. [...] I saw the state he was in [in cardiac arrest], my idea was not to leave because I was afraid of losing my son and not be there to see what happened [...] I wanted to see that situation for myself to be sure of what was going on (F10).

To witness the care and to confirm that it was done properly, even without having specific knowledge in the area is more likely to allow the evolution of the patient, be it good or bad. Still, the statement by F10 points to the importance of family presence for the elaboration of mourning, in the event of unfavorable outcomes.

These families who have experienced previous situations whose outcomes were unfavorable, causing irreversible consequences to the child, are influenced by these events and therefore defend their stay with the child during the emergency. It is noteworthy that the following statements are from the family of CSHCN: you're seeing what they are doing. [...] If they are giving the proper care [...] something happens and [the members of the health team] will give another explanation [...] Before , I believed everything they were saying. Now I stay on their toes. [...] They didn't pay enough attention [...] one of his problems was due to problems during his birth [...] (F4).

[...] when the situation of negligence happened [...] incorrect procedures at the time of delivery, which led to this emergency [cardiorespiratory arrest for neonatal anoxia] [...] so I think it's important to be together. [...] for security, not only for children, but for parents too. In a moment of uncertainty you can ask questions during the procedures [...] (F8).
These families do not fully trust the health team, as attributed to the prior negative outcome experienced due to the negligence of the team. These subjects favored being present during the emergency situation, due to their fear of another unfavorable outcome, being able to witness the care allowed them to feel more secure about the medical team's performance.

CSHCN family usually have knowledge regarding the clinical condition of their child due to accompanying the child's care on a daily basis and due to the frequent number of hospitalizations. Due to becoming used to the health team's conducts, they end up becoming more critical of the care that their children receive. These families also proved to be flexible with regards to staying with the child or not staying with the child during the emergency: I think everyone has a temper too. I imagine that for you [the health team] it is not easy if the mother gets agitated because the child is bad and you have to do the job and she is interfering with that, I believe that in this situation it is better not to be present [...]. Depending on the situation, it is complicated (F6).

A procedure that could traumatize me, in this case, think it was to protect me [previous situation in which the family member's presence was denied]. You know, I think it's the doctor who has to evaluate and decide whether the parent can or cannot [stay]. [...] Assess the emotional state of the family, but if he says that it is unadvisable to be together, I think she should be barred, but if the family member is calm, I think it is safe, is not out of control... I think they could be together (F8).

It is noticed, in light of these statements, that not all people are emotionally balanced enough to remain with their children in emergency situations and, depending on the family's stance, it may hinder the service. Moreover, in some emergency procedures considered more aggressive and complex, staying with their child during this time could prove traumatic for the family member.

Thus, these families demonstrate flexibility to stay or not, as reported situations in which they were requested to leave, and this request was accepted because they understood the position of the team. They reasoned that the professional team should evaluate each case and decide according to the situation and the emotional state of each family.

On the other hand, only one family made reference to preferring not to stay beside the child 
during the emergency, but still chose to remain. [...] We have to be together to comfort him [the child] and at that time instead of helping, we just make them [children] more nervous because we get quite nervous... so I'd rather not stay. We shouldn't be together, because instead of comforting the child, we end leaving the child more nervous (F2).

This mother preferred not to stay with the child during the emergency care because she was very anxious and believed that the child ended up feeling her nervousness and, thus, became weakened. He stated that the family should provide comfort to the child and, when this is not possible, there should be common sense to know when to withdraw from the situation.

\section{DISCUSSION}

Taking into account the profile of children seen in emergency situations, the CSHCN stood out. The denomination of children with special health needs who require such care, or who have temporary or permanent chronic physical behavioral or emotional conditions. ${ }^{12}$ These children need health services beyond which is required by children with normal development due to their clinical fragility. ${ }^{13}$

The results of this research is evident in another study, which showed that parents were in favor of remaining close to the child and said they contributed to the care, easing the fear of their children at the time of emergency. ${ }^{14}$ When the option to stay with the child was offered, they usually chose to stay, ${ }^{15}$ however, in most cases it is the health professionals who decides, if the family can be present with the patient during the emergency treatment or not. ${ }^{16-17}$

The presence of family during the child's hospital stay is a right guaranteed by Brazilian Law No. 8069/1990, which regulates the Statute of Children and Adolescents. ${ }^{18}$ However, there is no clarity in the legislation regarding the right of the family to stay with the child specifically during emergency situations.

It highlights the importance of family presence at all stages of the child's life, which is essential in times of illness. ${ }^{19}$ The patient and family-centered care model has been recommended as ideal for researchers around the world, being applied by health professionals in different institutions. ${ }^{8}$
Family participation should be encouraged by the health team, since it is an important resource in care, as they receive positive results in clinical improvement of the patient. ${ }^{8}$ The patient and familycentered care model includes a set of patient and family needs, which may include information, emotional support and allow close proximity between them during a health related crisis. ${ }^{19}$ From this perspective, health professionals must act to recognize that the family has the right to explain their understanding concerning the diagnosis and care of their child, fully and properly. ${ }^{20}$

The emergency team must make efforts starting with the recognition of the importance of the presence of the family, including the family in the decision-making process and allowing them the opportunity to actively participate in all stages of recovery and treatment of the patient. ${ }^{21}$

Statements of families can be seen in another study which highlights that the presence of family during emergency care is capable of supporting understandings of every process of patient care that requires emergency care, and reduces the doubts in relation to the efforts and performance of the team. ${ }^{21}$

Offering families the opportunity to be present during emergency care, allows health professionals to meet the needs of all involved in a time of extreme crisis. ${ }^{22-23}$

The hospital is seen as a place of healing, the intention of bringing a child to this place aims to ease the situation of risk and to seek resolution with health professionals. When the illness is very serious and evolves into death many parents cannot handle the speed in. which it occurs, making acceptance difficult. Thus, the presence of the family is encouraged according to studies which showed that the benefits outweighed the harm. This practice can help with the grieving process, and improve communication between health professionals and families. ${ }^{24}$ By allowing family presence during the emergency, it can help in the process of mourning and getting positive experience for both the patient and the family. ${ }^{25}$

In this context, the delay in providing news about the patient's progress is not well understood by the family, but in general, this is due to the fact that the priority at the time of emergency, is the care of the child whose life is at risk and at risk of future episodes. This is because the family members of patients who are receiving 
emergency care, are usually placed in a waiting area and are often left alone and uninformed by the health team. ${ }^{4}$

Health professionals should offer families the opportunity to witness the emergency care of their family member, while also recognizing that some people refuse the invitation and choose not to stay with the patient at this moment. ${ }^{26}$ Not all situations can be favorable for family presence. Considering this, the possibilities should be assessed according to the situation and uniqueness of each family member. ${ }^{19}$

The permission of family presence, if not properly planned, can have negative consequences for health professionals, patients and their family members. ${ }^{19}$ To ensure a quality service that offers the option to family members to stay with the patient in emergency or not, an elaborate policy and continuing education is required with the emergency service professionals. ${ }^{8,16,21,23,27}$

In this context, the development of an awareness program to promote family presence in emergency situations and recognizing the benefits that this practice provides to the child is highlighted. Thus, it is possible to promote attitudes, behaviors and values that promote the inclusion of the family in child care in different hospital settings, including emergency rooms. ${ }^{16}$

The medical and nursing schools should emphasize the important role of the family to the patients, especially in critical health care settings such as intensive care units and emergency rooms. ${ }^{28}$

The practice of family presence during emergency procedures can be encouraged and enforced by the nursing staff. Nurses should encourage practices considered beneficial for the patient, respecting patient and family autonomy with a view on the humanization of healthcare. ${ }^{29}$ Faced with the different realities experienced by families and health staff, studies suggest the need for policy and development protocols to facilitate the process of the presence of the family member with the patient in an emergency situation. ${ }^{8,16-17,19,21,25}$

However, more research is needed on the subject, in order to provide assistance to health professionals so that they can encourage the practice family presence in the emergency room, based on the principles of the care model focused on the patient and family in crisis situations. ${ }^{16}$

\section{CONCLUSION}

Family members considered staying with the child in emergency situations, critical and supportive, although sometimes distressing. They referred to the emotional and affective support provided by them as beneficial, by reducing the child's insecurity and fear and also referred to the need to see everything that is happening during the service. This reassures the family, because they know that everything possible is being done and they do not need to wait for information, which is often slow or fails to arrive.

The absence of information on the clinical status and procedures that are being performed generates anguish and suffering for the family, so being the informant of what is happening is a role that needs to be played by any member of the healthcare team.

Negative former experiences intensify the need for family members to be present at all times in child care. When following the whole process, it becomes easier to understand the outcomes that may happen, which enables better acceptance.

While being in favor of staying with the child, family members stressed the need to consider the specifics of each case. It was felt that many people who witnessed the emergency care, could possibly react in a way that may impair the performance of the health team.

The limitations of the study are related to the difficult approach to the subject, considered delicate, since pediatric emergencies can be very traumatic situations for patients and their families.

Developing strategies in nursing to facilitate such practice is recommended, promoting the inclusion of the family in child care in any situation, while respecting the uniqueness of each human being. Further investigation on the subject which can help develop policies and guidelines for the implementation of safe practice in health institutions is suggested.

\section{REFERENCES}

1. Erdmann AL, Sousa FGM. Cuidando da criança na Atenção Básica de Saúde: atitudes dos profissionais da saúde. O Mundo da Saúde. 2009; 33(2):150-60.

2. Marques JF, Santos HA. A criança como unidade de cuidado e campo de investigação da enfermagem. Arq Bras Ciênc Saúde [Internet]. 2012 [cited 2013 May 04]; 37(2):81-6. Available from: http://files.bvs.br/ upload/S/1983-2451/2012/v37n2/a3055.pdf 
3. Bauchner H. Parental presence during cardiopulmonary resuscitation: uncommon, but yet necessary? Arch Dis Child. 2014; 99:305-6.

4. Vavarouta A, Xanthos T, Papadimitriou L, Kouskouni E, Iacovidou N. Family presence during resuscitation and invasive procedures: Physicians' and nurses' attitudes working in pediatric departments in Greece. Resuscitation. 2011; 82(6):713-6.

5. Solà JA, Bravo SS, Cotanda CP, Maza VTS, Cubells CL.¿Ha aumentado la presencia de los padres durante los procedimientos invasivos en urgencias en los últimos años? Na Pediatr (Barc) [Internet]. 2014. [cited 2013 May 04]. Available from: http://dx.doi. org/10.1016/j.anpedi.2014.02.00

6. Cotanda CP, Cubellsy LJ,Fernández P. Deberían estar presentes los padres durante los procedimientos invasivos en urgencias?An Pediatr. 2009;70:293-6.

7. González GS, Tomás RJ, Etxaniz JS. Family presence during pediatric emergency procedures: the perspectives of family and medical staff. Emergencias. 2010; 22:175-80.

8. Al-Mutair AS, Plummer V, Copnell B. Study of nurses' attitudes from two Saudi hospitals. Nurs Critical Care.2012; 17(2):90-8.

9. Arrué AM, Neves ET, Buboltz FL, Jantsch LB, Zanon BP. Demanda de um pronto-socorro pediátrico: caracterização dos atendimentos de enfermagem. Rev Enferm UFPE Online [Internet]. 2013 [cited 2015 Aug 30]; 7(4):1090-7. Available from: http:/ / www.revista. ufpe.br>article>pdf_2363

10. Bardin L. Análise de conteúdo. $8^{\mathrm{a}}$ ed. Lisboa (PT): Geográfica Editora; 2011.

11. Brasil. Conselho Nacional de Saúde. Resolução n466, de 12 de dezembro de 2012. Regulamenta as pesquisas com seres humanos [internet]. Brasília; 2012. [cited 2013 Jun 13]. Available from: http:/ / www.ufrgs.br/ cep/resolucoes/resolucao-466-12

12. McPherson M, Arango P, Fox H, Lauver C, McManus M, Newacheck PW, et al. A new definition of children with special health care needs. Pediatrics.1998; 102(1):137-41.

13. Perrin JM, Romm D, Bloom SR, Homer CJ, Kuhlthau KA, Cooley C, et al. A family-centered, communitybased system of Services for Children and youth with special health care needs. Arch Pediatr Adolesc Med. 2007; 161(10):933-6.

14. Mangurten J, Scott SH, Guzzetta CE, Clark AP, Vinson L, Sperry J, et al. Effects of family presence during resuscitation and invasive procedures in a pediatric emergency department. J Emerg Nurs. 2006; 32(3):225-33.

15. Porter J, Dip G, Cooper SJ, Sellick K. Attitudes, implementation and practice of family presence during resuscitation (FPDR): a quantitative literature review. Int Emerg Nurs. 2013; 21: 26-34.
16. Ferreira CAG, Balbino FS, Balieiro MMFG, Mandetta MA. Presença da família durante reanimação cardiopulmonar e procedimentos invasivos em crianças. Rev Paul Pediatr. 2014; 32:107-13.

17. Mekitarian FFP, Angelo M. Presença da família em sala de emergência pediátrica: opiniões dos profissionais de saúde. Rev Paul Pediatr [Internet]. 2015. [cited 2015 Aug 28] Available from: http:// dx.doi.org/10.1016/j.rpped.2015.03.010.

18. Brasil. Câmara dos deputados. Estatuto da Criança e do Adolescente [Internet]. $7^{\mathrm{a}}$ ed. Lei $\mathrm{n}^{\mathrm{o}} 8.069$, de 13 de julho de 1990, e legislação correlata. Brasília, 2010. [cited 2013 May 18]. Available from: http://bd.camara.gov.br/bd/bitstream/handle/ bdcamara/785/estatuto_crianca_adolescente_7ed. pdf

19. Dougal RL, Anderson JH, Reavy K, Shirazi CC.Family presence during resuscitation and/or invasive procedures in the emergency department: one size does not fit all. J Emerg Nurs. 2011; 37(2):152-7.

20. Barbosa MAM, Balieiro MMFG, Pettengill MAM. Cuidado centrado na família no contexto da criança com deficiência e sua família: uma análise reflexiva. Texto Contexto Enferm. 2012; 21(1):194-9.

21. Porter JE, Simon JC, Sellick K. Family presence during resuscitation (FPDR): Perceived benefits, barriers and enablers to implementation and practice. Int Emerg Nurs. 2014; 22(2):69-74.

22. Dudley NC, Hansen KW, Furnival RA, Donaldson AE, Van Wagenen KL, Scaife ER. The effect of family presence on the efficiency of pediatric trauma resuscitations. Ann Emerg Med. 2009; 53(6):777-84.

23. Chapman R, Watkins R, Bushby A, Combs S. Assessing health professionals' perceptions of family presence during resuscitation: a replication study. Int Emerg Nurs. 2013; 21(1):17-25.

24. Porter J, CooperSJ, Sellick K. Attitudes, implementation and practice of family presence during resuscitation (FPDR): a quantitative literature review. Int Emerg Nurs. 2013; 21(1):26-34.

25. Dall'Orso MS, Concha PJ. Presencia familiar durante la reanimación cardiopulmonar: la mirada de enfermeros y familiares family presence during cardiopulmonary resuscitation: the look of nurses and family. Cienc Enfermeria. 2012; XVIII(3):83-99.

26. Jabre P, Belpomme V, Azoulay E, Jacob L,Bertrand L, Lapostolle F, et al. Family Presence during Cardiopulmonary Resuscitation. N Engl J Med. 2013;368:1008-18.

27. Tripon C, Defossez G, Ragot S,Ghazali A, BoureauVoultoury A, Scépi M, et al. Parental presence during cardiopulmonary resuscitation of children: the experience, opinions and moral positions of emergency teams in France. Arch Dis Child.2014; 99(4):310-5. 
28. Al Mutair A, Plummer V, O'Brien A, Clerehan R. Attitudes of healthcare providers towards family involvement and presence in adult critical care units in Saudi Arabia: a quantitative study. J ClinNurs.
2013; 23(5-6):744-55.

29. Balogh-Mitchell C. Is It time for family presence during resuscitation in the OR? AORN J. 2012; 96(1):14-25. 